\title{
Fluctuations in natural killer cell activity in early syphilis
}

\author{
JØRGEN R JENSEN, KRISTIAN THESTRUP-PEDERSEN, AND ELLIS FROM \\ From the Department of Dermatology and Venereology, University of Aarhus, Marselisborg Hospital, \\ Aarhus, Denmark
}

SUMMARY The natural killer cell activity was studied in 25 patients with primary, secondary, or latent syphilis before and after treatment. In primary syphilis natural killer cell activity was increased, especially in patients lacking circulating lipoidal antibodies. In patients who had become ${ }^{\subseteq}$ seroreactive in the lipoidal tests it was depressed in those with secondary and latent syphilis. The natural killer cell activity thus becomes activated by the syphilitic infection but is significantly reduced during progression of the disease. The importance of the natural killer cell activity in controlling syphilitic infection is questionable.

\section{Introduction}

Host defence against infection with Treponema pallidum is primarily dependent on cell-mediated immunity (CMI). ${ }^{1}$ Previous studies of $\mathrm{CMI}$ in syphilis have shown reductions of both in-vivo ${ }^{2}$ and in-vitro ${ }^{23}$ immune reactions. Recently, we reported a reduction in natural killer (NK) cell activity in patients with secondary syphilis ${ }^{4}$ and obtained evidence for the depressive role of circulating immune complexes. ${ }^{5}$ The present study extends our previous findings and reports activation of NK cell activity in early primary syphilis. The increased NK cell activity found at this stage of the disease is later reduced, possibly owing to the action of circulating immune complexes.

\section{Patients and methods}

Twenty-five patients with syphilis were studied; their ages ranged from 18 to 62 years (mean 39.4 years). Eight had primary, 17 secondary, and two latent syphilis; two of the secondary cases also had syphilitic hepatitis. All but four primary cases had positive results to lipoidal serological tests for syphilis. After confirmation of the clinical diagnosis blood was collected for immunological investigation. The patients were treated with procaine penicillin (PAM) 600000 IU daily for either 10 days (primary syphilis) or 14 days (secondary and latent syphilis). The immunological investigations were repeated one and two months after treatment.

Address for reprints: Dr J R Jensen, Department of Dermatology and Venereology, Marselisborg Hospital, Dk-8000 Aarhus C, Denmark

Accepted for publication 25 July 1982
Sixty-five control subjects, ranging in age from 20 to 56 years (mean $33 \cdot 1$ years), were studied in parallel.

\section{ISOLATION OF LYMPHOCYTES}

Twenty millilitres of heparinised blood $(20 \mathrm{IU} / \mathrm{ml}$ heparin) was obtained from patients and controls. Phagocytic cells were removed by the addition of $0.2 \%(\mathrm{w} / \mathrm{v})$ carbonyl iron to the blood, and $\stackrel{0}{\circ}$ lymphocytes were isolated using Ficoll-Hypaque $\stackrel{\mathscr{Q}}{\varrho}$ gradients. After separation the lymphocytes were $\overrightarrow{\overrightarrow{0}}$ washed three times in Hanks' balanced salt solution $\frac{3}{3}$ (HBSS) with $2 \cdot 5 \%$ (v/v) fetal calf serum (FCS) and resuspended in RPMI 1640 with $2 \cdot 5 \%$ FCS to a density of $1 \times 10^{6} / \mathrm{ml}$.

\section{NATURAL KILLER CYTOTOXICITY ASSAY}

Target cells were the human myeloid cell line K-562, clone 6 , mycoplasma-free. The cell line was kindly donated by S Bisballe, Institute of Human Genetics, $\frac{\text { ㄱ }}{2}$ University of Aarhus. K-562 cells were maintained in RPMI 1640 with $2 \cdot 5 \% \mathrm{FCS}$, penicillin $(100 \mathrm{IU} / \mathrm{ml})$, 을 streptomycin $(100 \mu \mathrm{g} / \mathrm{ml})$, and gentamicin $(1.5 \mu \mathrm{g} / \mathrm{ml}) \overline{\mathrm{N}}$ in a humidified $5 \% \mathrm{CO}_{2}$ atmosphere at $37^{\circ} \mathrm{C}$. Target $\sigma$ cells $\left(1 \times 10^{6}\right.$ cells) were washed once with HBSS and $\tilde{O}$ $0.1 \mathrm{ml}$ was labelled with $0.1 \mathrm{ml}(100 \mu \mathrm{Ci})$ of $\mathrm{W}^{\mathrm{N}}$ chromium-51 $\left({ }^{51} \mathrm{Cr}\right.$ ) (Radiochemical Centre, Amersham, UK) for 60 minutes at $37^{\circ} \mathrm{C}$. Labelled target cells were washed three times in cold HBSS with ${ }_{\odot}$ $2.5 \%$ FCS and resuspended in RPMI 1640 with $2.5 \% \stackrel{\leftrightarrow}{\sim}$ FCS to a density of $1 \times 10^{5}$ cells $/ \mathrm{ml}$. Effector cells 0 (lymphocytes) were then mixed with $1 \times 10^{4}$ target cells $\overrightarrow{0}$ in three effector-target (E:T) cell ratios (10:1, 25:1, and 100:1) in a final volume of $1.1 \mathrm{ml}$ in $11 \times 70 \mathrm{~mm} \mathbb{D}$ polystyrene tubes, centrifuged at $150 \times g$ for five $\stackrel{\circ}{0}$ 
minutes and incubated for four hours at $37^{\circ} \mathrm{C}$ in a humidified $5 \% \mathrm{CO}_{2}$ atmosphere. After resuspension and recentrifugation $0.55 \mathrm{ml}$ of the supernates were withdrawn and the release of ${ }^{51} \mathrm{Cr}$ determined in a gammacounter (LKB, Ultragammacounter). Tests were set up in triplicate. Spontaneous release (SR) was determined from target cells without effector cells and the maximal release(MR) of ${ }^{51} \mathrm{Cr}$ was determined from target cells in medium after hypotonic lysis. SR never exceeded $20 \%$ of MR. The following formula was used to calculate the percentage of specific lysis:

$$
\frac{c p m \text { Exp }- \text { cpm SR }}{\text { cpm MR }- \text { cpm SR }} \times 100 \%
$$

where cpm Exp refers to ${ }^{51} \mathrm{Cr}$ release from admixtures with effector cells.

Effector titration graphs were made for each experiment with specific lysis as a function of $\log \mathrm{E}: \mathrm{T}$ ratio. The number of effector cells required to give $50 \%$ specific lysis was determined from the titration curves. The results were expressed as lytic units: $1 \cdot 0$ lytic unit represented $50 \%$ lysis with $10^{6}$ effector cells.

\section{STATISTICAL ANALYSIS}

Student's $t$ test (two-tailed) was used.

\section{Results}

In patients with primary syphilis the NK cell activity was increased compared with both the controls $\left(t_{30}=3.93, \mathrm{p}<0.001\right)$ and the lytic activity of their lymphocytes one month after treatment of the disease $\left(t_{7}=3 \cdot 33, \mathrm{p}<0 \cdot 02\right)$ (table). Patients with secondary and latent syphilis had significantly reduced NK cell activity compared with the controls $\left(t_{55}=3 \cdot 88\right.$, $\mathrm{p}<0.001)$. After treatment the NK cell activity became normal. The increase in NK cell activity seemed to be an early event in primary syphilis and was found in the absence of circulating lipoidal antibodies (figure). Once patients with primary syphilis had become seroreactive in the lipoidal tests the NK cell activity declined. In secondary syphilis the decline in NK cell activity became even more pronounced (figure).

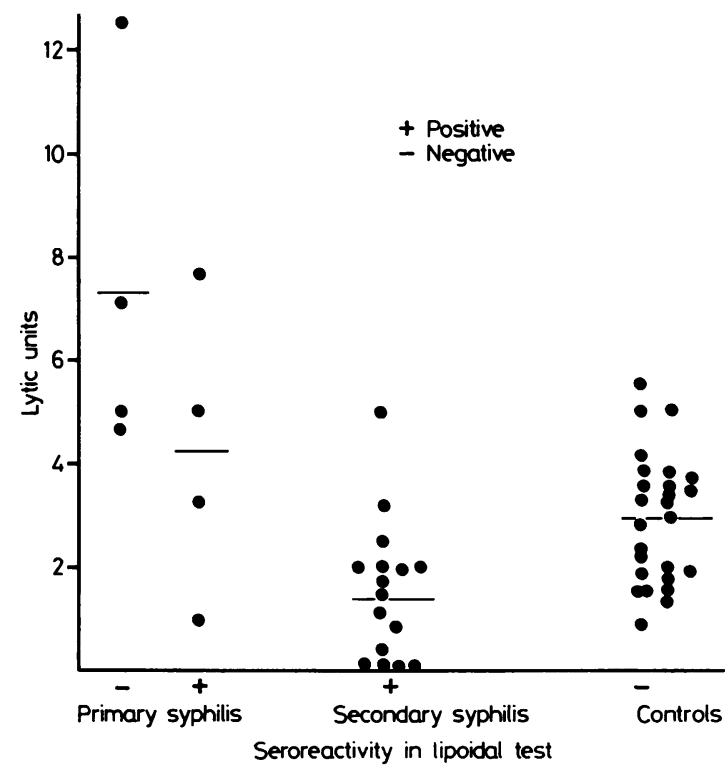

FIGURE Lytic units of lymphocytes from patients with primary and secondary syphilis before treatment in relation to serum reactivity in lipoidal serological tests.

\section{Discussion}

In a previous study we found a slight increase of NK cell activity in some patients with primary syphilis, all of whom had positive serological test results for syphilis. ${ }^{4}$ In this study we were able to investigate four patients with syphilis before their serum showed positive results in the lipoidal test; these patients clearly had increased NK cell activity. Thus NK cell activity may play a part in the body's defence against infection with $T$ pallidum similar to that which occurs against viral infections ${ }^{6}$ and cancer. ${ }^{7}$

The possible defence mechanism, however, seems to be unsuccessful, as determined by the reduced NK cell activity found in patients with later stages of the disease - that is, secondary and latent syphilis. We have reported previously that the depression of NK cell activity in secondary syphilis may be due to

TABLE Natural killer cell activity against $K-562$ of lymphocytes from patients with syphilis and from controls. (Figures in parentheses denote the number of patients studied).

\begin{tabular}{lllll}
\hline \multirow{5}{*}{ Stage of disease } & \multicolumn{4}{l}{ Mean lytic units ${ }^{*} \pm S D$ in relation to treatment: } \\
\cline { 2 - 5 } & Before & One month after & Two months after & Controls \\
\hline Primary & $5 \cdot 81 \pm 3 \cdot 42(8) \dagger$ & $2 \cdot 14 \pm 1 \cdot 83(8)$ & $3 \cdot 31 \pm 1 \cdot 27(8)$ & $3 \cdot 40 \pm 1 \cdot 68(24)$ \\
Secondary and latent & $1 \cdot 35 \pm 1 \cdot 32(16) \neq$ & $2 \cdot 33 \pm 2 \cdot 72(13)$ & $1 \cdot 94 \pm 1 \cdot 46(12)$ & $2 \cdot 85 \pm 1 \cdot 91(41)$ \\
\hline
\end{tabular}

-See text

+Significantly increased compared with controls (Student's $t$ test: $t_{30}=3 \cdot 93, \mathrm{p}<0 \cdot 001$ ) and with post-treatment level (paired $t$ test: $t_{7}=3 \cdot 33$, p $<0.02$ )

\$Significantly reduced compared with controls (Student's $t$ test: $t_{55}=3 \cdot 88, \mathrm{p}<0 \cdot 001$ ). 
circulating immune complexes. ${ }^{5}$ Suppressive serum factors were found in secondary syphilitic serum more than six weeks after treatment, ${ }^{5}$ and this may explain the slightly reduced NK cell activity presently found two months after treatment. Also, persistence of $T$ pallidum $^{8}$ and circulating immune complexes ${ }^{9}$ have been reported in patients after treatment of their disease.

NK cells are Fcy-receptor-bearing lymphocytes. ${ }^{10}$ Some are contained within the $\mathrm{T} \gamma$ cell population. ${ }^{11}$ The $\mathrm{T} \gamma$ cell population is slightly increased in patients with primary syphilis and significantly reduced in secondary syphilis, ${ }^{12}$ probably owing to an in-vivo blockage by circulating immune complexes.

The present study provides evidence of an activation of NK cell activity induced by infection with $T$ pallidum. Probably, the presence of circulating immune complexes inhibits the NK cell activation through blocking of $\mathrm{Fc} \gamma$-receptor-bearing lymphocytes. This may be yet another explanation for the prolonged clinical course of syphilis. ${ }^{13}$

This study has been supported by $\mathbf{P}$ Carl Petersens Fond, Bloddonorernes Forskningsfond, and the Danish Medical Research Council, grant No 12-1740. We are grateful to our two laboratory assistants, Ms Anni Jespersen and Mrs Jette Schj申dt, who have given expert assistance and constant help, and to Ms Lene Lyck Poulsen for secretarial help.

\section{References}

1. Pavia S, Folds JD, Baseman JB. Cell-mediated immunity during syphilis. A review. Br J Vener Dis 1978;54:144-50.

2. From E, Thestrup-Pedersen $K$, Thulin $H$. Reactivity of $\mathcal{O}$ lymphocytes from patients with syphilis towards Treponema pallidum antigen in the leucocyte migration and lymphocyte transformation tests. Br J Vener Dis 1976;52:224-9.

3. Fulford KWN, Brostroff J. Leucocyte migration and cell- $\bar{\omega}$ mediated immunity in syphilis. Br J Vener Dis 1972;48:438-8.

4. Jensen JR, Thestrup-Pedersen K, From E. Natural killer cell $\mathrm{Q}$ activity in syphilis. Arch Dermatol Res 1982;272:163-5.

5. Jensen JR, Jørgensen AS, Thestrup-Pedersen $K$. Depression of $\mathscr{C}$ natural killer cell activity by syphilitic serum and immune $\overrightarrow{0}$ complexes. Br J Vener Dis 1982;58:298-301.

6. Trinchieri G, Santoli D. Anti-viral activity induced by culturing lymphocytes with tumor-derived or virus-transformed cells. $\vec{\omega}$ Enhancement of human natural killer cell activity by interferon $\mathbb{Q}$ and antagonistic inhibition of susceptibility of target cells to lysis. $\stackrel{\mathscr{\infty}}{+}$ JExp Med 1978;147:1314-33.

7. Herberman RB, Holden HT. Natural killer cells as anti-tumor Gु effector cells. $J$ Natl Cancer Inst 1979;62:441-5.

8. Tramont EC. Persistence of Treponema pallidum following $\vec{\omega}$ penicillin G therapy. JAMA 1967;56:221-2.

9. Engel S, Diezel W. Persistent serum immune complexes in $\mathrm{O}$ syphilis. Br J Vener Dis 1980;56:221-2.

10. Jondal M, Pross HF. Surface markers on human B- and T-lymphocytes. VI Cytotoxicity against cell lines as functional T marker for lymphocyte subpopulations. Int $J$ Cancer $D$ 1975; 15:569-610.

11. West WH, Cannon GB, Kay HD, Bonnard GD, Herberman RB. Natural cytotoxic reactivity of human lymphocytes against a myeloid cell line: characterization of effector cells. J Immunol 1977; 118:355-61.

12. Jensen JR, From E. Alterations in $\mathrm{T}$ lymphocytes and $\infty$ T-lymphocyte subpopulations in patients with syphilis. $\mathrm{Br} J$. Vener Dis 1982;58:18-22.

13. Wright DJM, Grimble AS. Why is the infectious stage of syphilis prolonged? Br J Vener Dis 1974;50:45-9. 